\title{
Causes, Features and Consequences of Financial Crises: a retrospective cross-country analysis
}

\author{
Musa A. Subeh \\ Head of Accounting Section, Bethlehem Municipality, Palestine. \\ Vita Boychenko \\ $\mathrm{PhD}$, Deputy Director at TaskomBank, Ukraine.
}

\begin{abstract}
Given the volatility of financial crises around the world, there is an urgent need to investigate the causes of the emergence, the peculiarities of development and the consequences of financial crises in the countries of the world.

Among the main causes of financial crises, the author highlights the frequent collapse of stock markets, the rapid development of new stock instruments without their regulation and control of their circulation, sharp flows of capital between different parts of the world, large volumes of speculation, weak regulatory regulation of the stock market.

The study of economic relations in the chain "financial crisis - the policy of regulators on the elimination of its consequences - the change in the strategies of financial agents in the financial markets" for 17882008 proved that the behavior of financial agents in the future depends on the nature of the crisis. As a result it is possible to distinguish four global strategic vectors of performance-UAH Duration, nights financial agents HHI XXI century, which is formed in response to the financial crisis and gar post-crisis regulatory action.

Based on the generalization of the experience of different countries, four types of financial crises have been identified in the article, which have often occurred simultaneously in the same countries. This suggests that in the absence of a well-balanced public anti-crisis economic policy or its misuse, financial crises of the same type may generate financial crises of other types, deepening the overall level of economic decline of the country and complicating the post-crisis recovery. Such crises are suggested to be called "derivative crises". It has been determined that for optimal strategic planning of development in the post-crisis period, financial agents should also consider the probability of an emerging crisis during or after the end of the basic crisis (the crisis that originated).
\end{abstract}

Key words: financial crises, types of financial crises, cross-country analysis, derivative crises.

JEL Classification: B26, G01.

(C) The Authors, 2018. This article is published with open access at Sumy State University.

\section{Introduction}

Among the main causes of financial crises, the author highlights the frequent collapse of stock markets, the rapid development of new stock instruments without their regulation and control of their circulation, sharp flows of capital between different parts of the world, large volumes of speculation, weak regulatory regulation of the stock market. The study of economic relations in the "financial crisis - the policy of the regulators on the elimination of its consequences - the changes in financial agents 'strategies for financial markets" for 17882008 proved that financial agents' behavior in the future depends on the nature of the crisis. As a result, it is possible to distinguish between four global strategic performance vectors - UAH Duration, night financial agents HHI XXI century, which is formed in response to financial crisis and long peccritical regulatory action.

Based on the generalization of the experience of different countries, there are four types of financial crises identified in the article, which often occurred simultaneously in the same countries. This suggests that in the absence of a well-balanced public anti-crisis economic policy or its misuse, the same type of financial crises can generate other types of financial crises, deepening the overall level of economic decline in the country and complicating post- crisis recovery. Such crises are suggested to be called "derivative crises". It has been determined that for optimal strategic planning of development in the post-crisis period, financial agents should also consider the emerging crisis in the aftermath of the end of the basic crisis (after the crisis). 


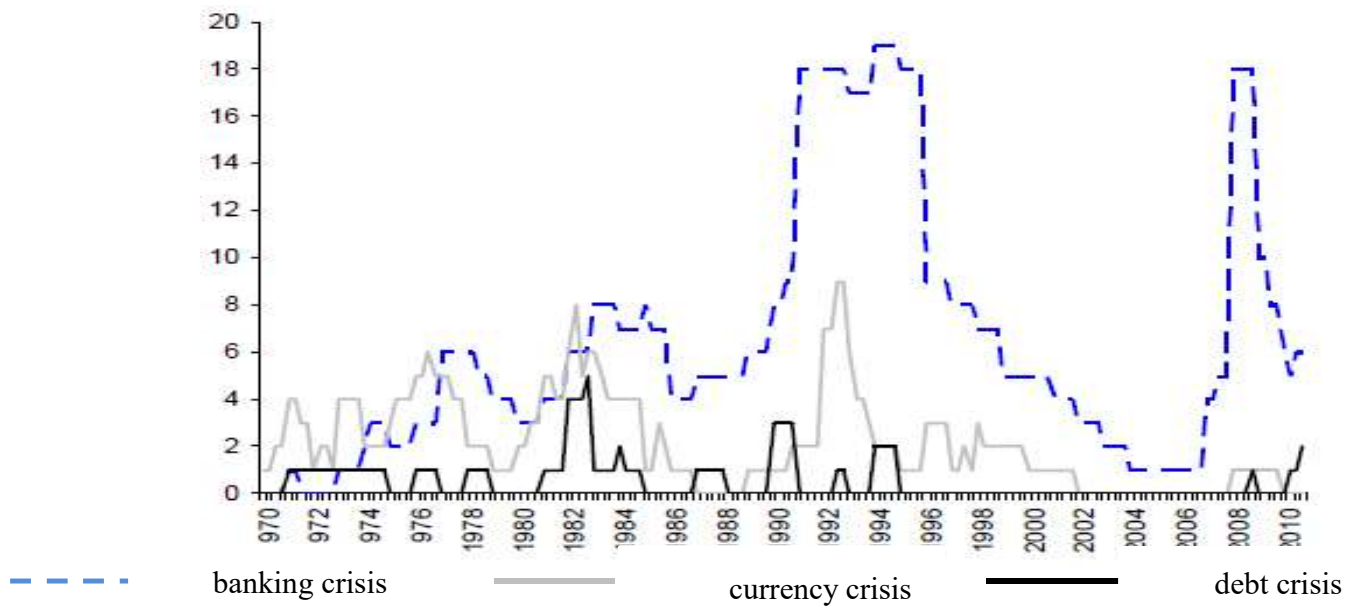

Figure 1. The number of developed countries in crises

As can be seen from Figure 1, the largest banking crises were crises in 1990-1996 and 2008-2009, foreign exchange rates in 1982 and 1992-1993, and debt in 1982, while currency crises were always preceded by other types of crises, from which it is possible to put forward two hypotheses: 1) the very currency crises led to the development of other types of crises; 2) currency stability is most sensitive to the impact of negative externalities, and therefore the very exchange rate first reflects the beginning of crisis phenomena in the economy. It is interesting to note that, if in 1976 and 1982 the currency and banking crises took place in the same number of countries, then since 1992, the developed countries managed to stabilize exchange rates, which is already in 2008 against the backdrop of deep banking crisis in the world, the global currency crisis was not observed.

To date, the topic of identification of economic crises and their phases is quite popular in the academic literature, most likely due to the recent departure from one of the largest financial and economic crises in the world since the Great Depression, some countries are still experiencing the consequences of that crisis, in some of them it has a continuation in the form of other types of crises. The most common types of economic crises that occur in developed countries are currency, banking, debt, and the balance of payments crisis, or, as it is often called in foreign scientific literature, the "sudden stop" crisis. Other types of economic crises can be a combination of the above and come out of them. Analysis of the development of crises in developed countries over the past 45 years indicates that, first of all, the currency crisis develops, and it is followed by debt and banking. On the other hand, the effective development of monetary policy instruments has led to the stabilization of foreign exchange markets, resulting in the developed countries of the world having practically no currency crises over the past 20 years. However, for developing countries, this is not fair, they remain dependent on monetary stability, which is supported by the current trends in the economic development of Ukraine, where currency destabilization has led to a banking and debt crisis. Regarding the strategic priorities of financial agents in the lending market during various stages of the economic cycle, it should be noted that for the European Union is characterized by rising interest rates on loans in the pre-crisis period and during the crisis and the rapid decline in the cost of loans to reach the peak financial crisis, unlike the European countries in Ukraine, the increase in interest rates is more typical of the crisis and post-crisis period, which in our opinion slows the process of getting out of the crisis, and therefore the state regulator I have interest rates in the credit market is an extremely important issue today. Given the volatility of financial crises around the world, there is an urgent need to investigate the causes of the emergence, especially of the development and consequences of financial crises in countries around the world.

\section{Literature review}

In recent years, the issue of defining indicators of early warning and diagnostic models of crises has renewed its relevance in discussions among scientists and politicians in connection with the financial crisis of 2008 and further financial and economic turbulence. One of the key scientific papers about the nature of the emergence and deployment of financial crises is the work of G. Kaminsky and K. Reinhart, which in essence have proven that the inflow of credit and investment capital is preceded by a boom in economic activity. Recent studies of banking crises and balance of payments crises have shown that housing prices and general liquidity can be used as indicators of early diagnosis for these types of crises. Francois and Saravelos suggest 
that excessive overvaluation of the currency and insufficient central bank reserves be considered as the main indicators of the early diagnosis of the financial crisis.

Scientists define the currency crisis as a consequence of the pressure of foreign currency on the local. Such pressure is most often manifested in the desire of economic entities to invest in assets in foreign currency. Several variants of such behavior are possible: an increase in the money supply by the government to solve the problems of the state budget deficit, which will cause investor anxiety; the devaluation of the national currency is caused by speculative pressure on the currency market, which aims to increase the exchange rate, and so on. In any case, to stabilize the market and reduce the rate of devaluation, the central bank of the country generally sells currency at the expense of its foreign exchange reserves. Given the insignificant level of devaluation and sufficient volumes of gold reserves of the central bank, exporters may receive additional income at the expense of devaluation, while households do not experience significant deterioration in their own welfare. In the case of a leap-type devaluation, when the fall of the exchange rate exceeds $10 \%$ over a fairly short period, it may lead to unwinding of inflation, changes in market outlets and market conditions. The first models aimed at developing a system of indicators for early diagnosis of the currency crisis, which would take into account the deficit of the state budget, the volume of international reserves and expectations of the subjects of the national economy, were created in the 1960's. Existing models for diagnosing currency crises can be divided into 3 groups, each of which is characterized by an emphasis on certain modeling factors and foresight of the currency crisis. Models of the first group were developed by P. Krugman and P. Garber. In their opinion, the main causes of the currency crisis are the growth of public debt and the government's inability to maintain a deficit of the state budget at a given level. These models focus on assessing the possibility of losing stability in the exchange rate, as this is seen as the most negative effect of the currency crisis, which causes the most devastating economic consequences.

In recent years, the issue of defining indicators of early warning and diagnostic models of crises has renewed its relevance in discussions among scientists and politicians in connection with the financial crisis of 2008 and further financial and economic turbulence. One of the key scientific papers about the nature of the emergence and deployment of financial crises is the work of G. Kaminsky and K. Reinhart, which in essence have proven that the inflow of credit and investment capital is preceded by a boom in economic activity. Recent studies of banking crises and balance of payments crises have shown that housing prices and general liquidity can be used as indicators of early diagnosis for these types of crises. Francois and Saravelos suggest that excessive overvaluation of the currency and insufficient central bank reserves be considered as the main indicators of the early diagnosis of the financial crisis.

Scientists define the currency crisis as a consequence of the pressure of foreign currency on the local. Such pressure is most often manifested in the desire of economic entities to invest in assets in foreign currency. Several variants of such behavior are possible: an increase in the money supply by the government to solve the problems of the state budget deficit, which will cause investor anxiety; the devaluation of the national currency is caused by speculative pressure on the currency market, which aims to increase the exchange rate, and so on. In any case, to stabilize the market and reduce the rate of devaluation, the central bank of the country generally sells currency at the expense of its foreign exchange reserves. Given the insignificant level of devaluation and sufficient volumes of gold reserves of the central bank, exporters may receive additional income at the expense of devaluation, while households do not experience significant deterioration in their own welfare. In the case of a leap-type devaluation, when the fall of the exchange rate exceeds $10 \%$ over a fairly short period, it may lead to unwinding of inflation, changes in market outlets and market conditions.

The first models aimed at developing a system of indicators for early diagnosis of the currency crisis, which would take into account the deficit of the state budget, the volume of international reserves and expectations of the subjects of the national economy, were created in the 1960's.

Existing models for diagnosing currency crises can be divided into 3 groups, each of which is characterized by an emphasis on certain modeling factors and foresight of the currency crisis.

Models of the first group were developed by P. Krugman and P. Garber. In their opinion, the main causes of the currency crisis are the growth of public debt and the government's inability to maintain a deficit of the state budget at a given level. These models focus on assessing the possibility of losing stability in the exchange rate, as this is seen as the most negative effect of the currency crisis, which causes the most devastating economic consequences. 


\section{Results}

In the scientific literature, the emergence of financial crises is inextricably linked with the cyclical development of the economy. Thus, scientists distinguish the following types of cycles of economic development: short-term (average duration 3-5 years), the main causes of cyclicality are, as a rule, the activation of financial transactions in the stock and financial markets; medium-term (average duration 10-20 years); the main causes of cyclicality are most often structural changes in the national economy and significant capital inflows between gas companies or sectors of the economy; long-term (the duration varies within 50 years). These cycles are usually triggered by revolutionary changes in production technologies and can have both national and international scales.

A critical period in the functioning of a particular system, during which it is exposed to external and internal influences, requires qualitative changes in the mechanisms of forming the reaction of the system to stimuli. From the point of view of the theory of cycles of a market economy, the crisis is called the phase of the economic cycle, during which there is a renewal of the distorted by the phase of active growth of proportions due to lower production volumes, rising unemployment, increase or decrease in prices, devaluation / revaluation and others. According to scientific studies of economic and financial crises from the late 18th century. In the economies of the industrialized countries there were 4 long-term economic cycles (1789-1849, 1849-1896, 1896-1938, from 1952-2007). Determine the key causes of the emergence and development of the major economic crises for 1788-2008, and we will analyze to what start-up changes in the development of banks and banking systems this has led. Also, we will explore the crisis-based toolkit of governments and banking system regulators, which was used in crisis and post-crisis periods.

The first crisis, from which, as a rule, begins the study of economic cycles in general and crises in particular, considered the economic crisis in France in 1788. Over the past several years, France experienced significant economic growth, but then came the economic stagnation - there was a crisis of overproduction, which resulted in a sharp increase in unemployment and a large number of manufactories. The situation was also aggravated by the poor harvest of cereals and the drop in their stocks, which led to an increase in food prices. This, in turn, led to the emergence of social tension and eventually in 1792 to the Great Franz-zug Revolution. France turned into a republic (Louis XVI was starved, and monasticism was eliminated). The newly formed government implemented an administrative reform, aimed basically to simplify the structure of the apparatus of state administration. Another unpopular step was the prohibition of trade unions (Leshapelier's law). Among other measures taken by the new government were: increased tax pressure on the economy; harassment of the church, confiscation of its property; sale of state property; increase of the state debt and other ways of covering the growing budget deficit. In money and credit system, paper money (assignments) was introduced, the main feature of which was their provision of national property, not gold.

The next crisis, which also took place in Europe, was a crisis in the UK. Its beginning is considered to be 1825 , however, in 1836, it broke out with renewed vigor and turned over to the United States, Germany and France, which were economically and financially closely associated with Britain, which brought the crisis into a first international crisis. The study of the causes of this crisis shows that in the early 19th century. European investors have invested heavily in South American mines. The resulting metals were subsequently actively traded on the London Stock Exchange. Speculative trading in precious metals destabilized the market, which led the Bank of An-gliya to intervene and spend large volumes of its own reserves. As a result, you called the stock market crisis, which subsequently caused a banking crisis. The loss of a large market for large volumes of gold and silver has led to the closure of a large number of mines and the economic crisis in South America. The response of the regulator to this crisis was the adoption in 1826 of the so-called "Banking Charter Act", which was intended to facilitate the restoration of the banking system. In accordance with this law, joint-stock banks have the right to issue their banknotes, but their circulation was not allowed within a radius of 80 kilometers from London. This period is also defined in history as a period of active development of savings banks in Europe, whose activity was mainly focused on attracting savings to workers of factories and plants whose incomes began to grow rapidly. The inter-crisis period was short-lived, and in 1836 the stock market crisis in Great Britain began for 8 years, culminating in 1843 . The main cause of this crisis was a surge in active trade in the cotton market in America. This led to the flow of financial capital from the UK to the United States. Another factor was the poor harvest of corn in England. Insufficient after the previous crisis, the volume of international reserves of the Bank of England forced the latter to raise the discount rate. The increase in the value of capital was caused by structural shifts in the banking system and the stock market crisis 
in Britain. The emergence of charisma, as a new form of workers' unions, in contrast to trade unions, led to the formation of a new political movement whose purpose was to represent the interests of the working class. The most significant economic and financial outcomes of this crisis were the devaluation of national currencies and the bankruptcy of many banks. 1848 was marked for Europe by a series of bourgeois revolutions (in the literature this phenomenon is called "Spring of Peoples"), which was caused by growing injustice in the distribution of income from production and the flowering of the trade union movement. The economic consequences of these revolutions actually led to the first world economic crisis in 1857, it was covered by all the most developed countries of the world. In the course of the industrial revolution, the metallurgical, machine-building, and mining industries had a powerful impetus for development. This in turn led to mass bankruptcy of small farms and investment banks.

More than 10 European countries were covered by the stock market crisis in 1846-1847 as a result of political and economic problems in Europe at that time. At the same time, the largest liquidity in the stock exchange was used by actively developing railway companies. However, this hype also had the opposite side - it was difficult to appreciate the investment attractiveness adequately, and many of these companies went bankrupt. The escape of investors from the stock market had a negative impact on the banking sector, which largely provided the relevant capital, the banking systems of Germany, the United Kingdom and the Netherlands, which have not recovered since the previous crisis, have suffered the most. Social upheavals and the movement for the rights of workers have led to dramatic changes in labor policy - the working day has been reduced to 10 hours. This, in turn, prompted the owners of factories and factories to invest in the search for automation and mechanization of production. This led to the rapid development of machine-building, which came in first place both in volumes of production and profitability. The consequence of such a change in production efficiency was the bankruptcy manufaktor and the rapid development of factories and factories.

The above economic crises were mostly local. The first world economic crisis began in the United States in 1857. The main causes of this crisis are the aforementioned bankruptcy of railway companies and the collapse of the US stock market. This caused panic and destruction in the banking system. Due to the existence of financial interconnections between the United States and Britain, the last crisis hit the same year, and in the following year it spread to other European and South American countries. During 18571861 the world crisis hit the majority of countries of the world. Researchers point out that the main causes of this crisis were the growing strength of the investment capital between the United States, Europe and South America as a result of pro-policyist government policies. The end of the 19th century was marked by a powerful crisis in the United States, due to the complexity of macro- and microeconomic factors, as well as reckless, and sometimes even frankly, false actions of the regulators of the financial system. At the beginning of the Civil War, the US Treasury needed cash assistance, which it turned to local banks. Treasury received loans, but the US government failed to repay them on time and in full, causing a crisis of liquidity of American banks. As a result, a banking system crisis lasted until 1865. Under war conditions, it was impossible to secure the entire territory of the country from the same emission center, and therefore the rights to the issue were provided to federal banks, which by the end of 1861 was over 1600. They produced more than 7,200 different types of banknotes, $65 \%$ of which were counterfeit or invalid. As a result, in 1864 , the annual rate of inflation exceeded $220 \%$. To correct the situation, the federal law "On the National Banking System" was adopted, which granted the right to issue money only to national banks that were created under this law. This allowed to stop inflation growth and stabilize the banking system for almost 25 years. In 1890, a new Tactical crisis took place in the United States, which I often call "crisis of one bank" or "the crisis of the Bank of Bering". Bank Baring (Great Britain) specializes in investments in infrastructure projects (construction of railways) and became the native bank of the country. Reducing the level of profitability of such projects and the decline in liquidity of related securities on US stock exchanges has led to the bank's large losses, resulting in it declared bankruptcy. The result was a panic in the population, a decline in bank confidence, a massive outflow of deposits and a liquidity crisis in the banking system. As an anti-crisis measure, the UK government has taken a large loan in France and Russia to overcome the consequences of the banking crisis and rescue Baring Bank. Thus, the financial crises of the 18th and 19th centuries. We note the offensive: during this period, there were several large-scale, even world-class (1836-1843, 1857-1861) crises, the main causes of which were structural changes in production and monetary systems of countries, sharp changes in productivity labor, the difference in the profitability and risk profile of certain types of economic activity. The main actions of governments and central banks before, during and during the first years after the end of the crisis were: 
protectionist policies of governments, stimulating investment in the most profitable and least risky sectors of eco nomics, changing regulatory requirements for banks that finance the priority for state industry and others like that. The result of these crises, as well as the actions of governments, was the change in the strategic vector of the activities of financial agents in the market towards its narrow specialization.

In the early twentieth century, the largest financial crisis was the exchange crisis in the United States in 1907-1908. Prior to its emergence was mainly led to an increase in the discount rate in the UK from $3.5 \%$ to $6 \%$. As a result, in search of higher returns, capital from the United States began to flee to England, as British securities became more attractive investment than US securities. This caused a collapse on the New York Stock Exchange. The worst hit by this crisis was the American trust fund Nickerborker, which had almost 20,000 clients in that most of which were from Europe. The loss of their wealth led to the spread of the crisis and the European space.

The First World War could not but lead to significant financial turmoil in the local and international markets. The war has become the cause of a massive sale of securities from its own repute-broked by the governments of the United States, Britain and France. They needed large amounts of additional funding for their armies. The same was true of Germany. Financial crisis of the first World War covered almost all parts of the world, where the functioning of the stock markets, including Japan. The size of the damage caused by the war and the financial crisis was more than 180 billion dollars. USA. While the world recovered after the First World War, trying to overcome the recession and deflation, the Russian Empire raged civil war. There were painful processes of the co-Military revolution and the formation of the Soviet Union. Redistribution at the Washington and Paris conferences of spheres of influence has caused chaos in the international migration of investment capital, which has become the cause of many currency and banking crises in most capitalist countries. This can be characterized as a global post-war crisis that lasted 5 years (from 1919 to 1923 ) and was predominantly monetary and / or banking.

In 1927, in the United States there was a stock exchange "boom." On the one hand, the capital market in the United States was substantially filled with resources from Latin American and European countries, but on the other hand it caused a shortage of capital and a number of debt and currency crises in these countries. Most of all, it affected Argentina, Brazil and Australia. Taking into account the old colonial ties between the above-mentioned countries, the capital shortage caused a drop in US production, which at that time was the largest economy in the world. Coupled with the high rates of production that the US economy has been experiencing, it has caused a crisis of overproduction, which led to deflation. The fall in prices, and, consequently, sales volumes, unfavorable conditions on foreign markets led to an increase in unemployment in the United States and a deficit in the state budget. All these events triggered a massive bankruptcy of companies, which resulted in October 24, 1929, in the "Black Thursday", a day during which the collapse of stock and commodity indices on all US exchanges exceeded $70 \%$ [137]. The scale of the economic downturn has become remarkable GDP volumes in individual countries have fallen by 2 times, while unemployment has risen by $300-400 \%$, and averaged over $25 \%$. The inability of governments and central banks to control inflation became the reason for the abandonment of the gold standard and the establishment of absolute state control over the circulation of gold in the economy.

Such structural changes in money circulation have caused mass bankruptcy of banks. Given this, taking into account the experience of the Baring Bank (which was the prototype of the first savings bank) and the UK experience in developing a deposit guarantee system, the US government has taken a number of regulatory measures that have shaped the face of the US banking system for many years to come. In particular, the law of Glass-Stigol was passed in the USA, which essentially banned foreign banks from serving the population, and commercial banks (serving the population) - to engage in investment activities. A federal US deposit insurance corporation was also created, which continued the British practice of forming a system for storing public deposits in order to restore the credibility of the latter to the banking system and return deposits to it. In the social sphere, a number of anti-crisis steps were also taken, including for young people, employment guarantees, for older people, unemployment insurance, and pensioners were introduced for pensioners. "Great Depression" has become the reason for the intensification of trade wars for markets of developed countries. The US refuses the gold standard to trigger a currency crisis of 2 years, which extended the Great Depression. The US government unveiled its de-regulatory plans, which led to the massive purchase of the US dollar and the exchange of gold for gold. This caused a devaluation of the dollar, and it became the first example of the use of the exchange 
rate as a tool of trade warfare. Since 1934, the period of domination of the goldenward standard has begun.

Thus, summing up the crisis of the first half of the twentieth century, can konstatu-wool, it was a very difficult period, accompanied in addition to World War still significant structural changes in the monetary and financial systems of the world. Changing the paradigm of money circulation, which lasted for centuries, caused a shock on all continents and in all spheres of economic life. The USA, the countries of Europe and Latin America have suffered the most during this period from crises. The main reasons for the financial crisis should provide frequent stock market crash, the rapid development of new financial instruments without their proper management and control of their turnover, sudden capital flows between different parts of the world, a large amount of speculation, a weak stock market regulation. The main regulatory powers of governments and central banks of countries hit by the crisis were aimed at restoring public confidence in banks, fighting outflow of bank deposits. At this time introduced the first complete system to guarantee deposits in the US (UK Lane st deposit insurance system was introduced several decades earlier, after the crisis, banks Behring, but it has several limitations and did not cover the whole market), adopted by con Glass -Stygoola, which differentiated public service and investment activities for more than 70 years. These factors have forced banks to pay more attention to the sector domohospo households, as one of the most profitable and stable customer segments that the future obumo-Howling active development of retail banking in the US and worldwide.

The next 40 years of economic development of countries (except the years of World War II) had no significant financial turmoil, despite the transition to the Bretton Woods monetary system in 1944 (in fact, this transition took place much earlier, and the Bretton Woods conference only strengthened status quo, which at that moment was finally formed). The decline in oil production countries belonging to OPEC to raise oil prices (the goal was achieved - just one day after the announcement of the decision, the price of oil increased from 3 to 5 dollars. US 1 barrel, and for 1974 - exceeded USD 11) launched the first world energy crisis, which also had significant financial implications (Fig. 2)

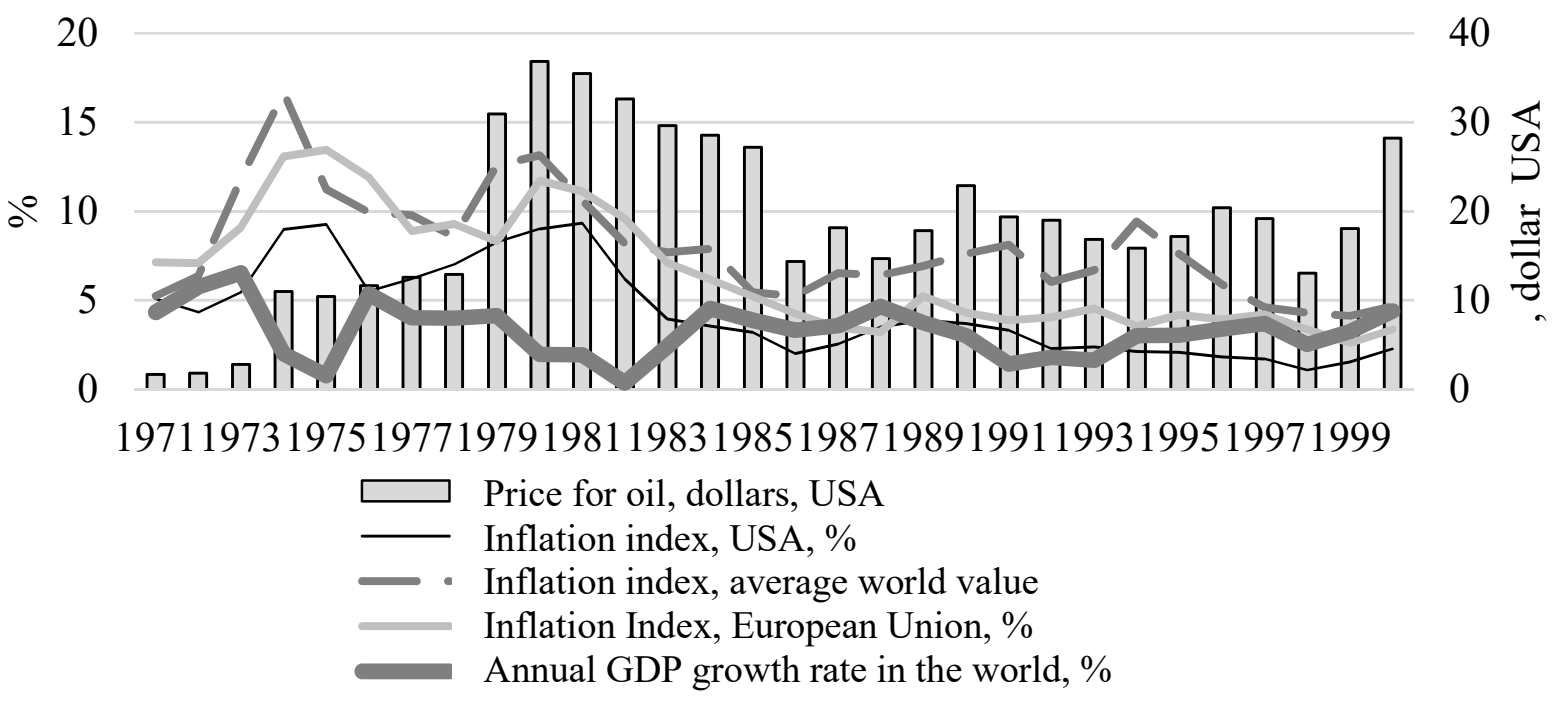

Figure 2. Dynamics of changes in oil prices and the index of inflation in the second half of the twentieth century

The rise in crude oil prices was accompanied by an increase in inflation, which led to a sharp deceleration of economic growth. This led to systemic crises in all major sectors of the economy in all countries of the world. Given that in many countries oil is a key commodity in the trade balance, it initially caused a crisis of balance of payments, and subsequently in many countries and currency crises. The massive devaluation of national currencies led to the abandonment of the Gold Devel- opment Standard at the Jamaican Conference of 1976 and the transition to the use of SDRs as an international equivalent of value. The next massive crisis took place in 1987, namely in October. Researchers do not distinguish between any significant macroeconomic or political preconditions for the emergence of this crisis. Most of them are inclined to believe that it was provoked by the collapse of the capitalization of several of the largest companies of the time that caused the "bearish pressure", which on October 19, 1987, dropped the Dow Jones index by more than 22\%.

Following the US stock market, stock exchanges in Hong Kong, Australia and Canada collapsed. This crisis in the literature is called "Black Monday", and it ended in 1992. Among the specialties of the US stock market 
at that time, the significant volumes of trading in securities of large institutional investors (more than $50 \%$ of trading on the NYSE before " black Monday-com "); for 8 months of 1987, the growth of share prices has reached $44 \%$; the ratio of average profits per share to their rates has become speculative. The growth of volumes of speculative operations was a prerequisite for the emergence of a stock exchange boom, which increased the gap between economically justified and exchange prices. The exchange crisis in a very short time has become global. This was partly due to the intensification of globalization processes, especially in the financial sector. Despite the fact that the crisis in developed countries began, very quickly it turned into developing countries, which showed a strong interconnection between them. During this crisis, the countries of South America and Southeast Asia, in particular, Hong Kong, suffered the most. Among the measures taken by regulators during this crisis, it should be noted measures to limit the exchange rate fluctuations in the stock market: restrictions on automatic trading (with the help of computer programs), including a complete stop of trade if fluctuations exceeded $10 \%$. The largest collapse of the stock market in Asia since the mid-twentieth century was held in 1997. Devaluation of local currencies and the deficit of payment balances of Asian countries caused a massive outflow of investors from the economies of these countries. According to econominations, this crisis has led to a fall in GDP in Asia and Oceania by more than 1 trillion. dollars USD or 14\% (Fig. 3).

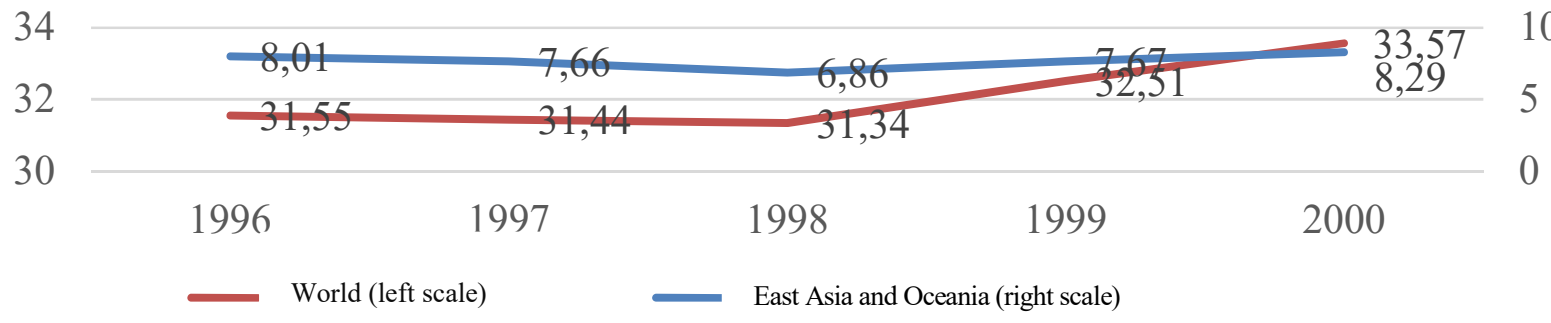

Figure 3. Dynamics of World GDP and GDP of East Asia and Oceania in the 1990s, trillion. dollars USA

This financial crisis has sprouted in Indonesia, South Korea, Thailand, the Philippines, Hong Kong, Taiwan and Singapore - new industrialized countries that have formed a powerful economic potential, with their new models of national economy. These countries have experienced another cyclical upturn since the 1980's, with corresponding GDP growth, exports, gold reserves and deficit-free budgets. One of the most severe financial crises on the territory of the former Soviet Union took place in 1998-1999. This crisis began in the Russian Federation because of the critically large public debt, the decline in world prices for raw materials and the large volume of state short-term bonds, for which caused arrears on payments. The consequences were as follows: the exchange rate of the ruble against the US dollar in August 1998 - January 1999 collapsed from 6 to 21 rubles. for US Dollars (more than 3 times). Under the influence of this crisis, the Ukrainian stock market experienced one of the largest disruptions in its history, and the National Bank of Ukraine introduced a ban on the implementation of advance payments by residents for import contracts. Settlements in volumes over 10 thousand dollars. The USA was spent only in the form of an acre-baby or a collection. The Ministry of Finance of Ukraine made attempts to restructure the state debt with a delay of payments for 3-5.5 years. Some banks were prohibited from conducting currency exchange transactions. On the UMBB, trading was stopped due to a "technical break". On the "black-m" market the value of the US dollar exceeded 3.5 UAH. A ban was introduced for banks to pay dividends and repurchase shares. More than fifty executives of legal entities owed for foreign loans were arrested under government guarantees. The authorized capital of banks has fallen by $35 \%$, deposits of the population have decreased by $13 \%$. For Ukraine, this was a rather difficult crisis at the start of the formation of a new national currency - the hryvnia. However, in 2 years the consequences have been virtually overcome, and the economy has begun a rapid recovery.

Analyzing the causes and consequences of the crises of the second half of the twentieth century. we can note that the main causes of the financial crises of this period were price bubbles in the oil market, sharp capital inflows between financial centers, China's exit into international capital markets, and high volatility of international flows of investment capital as a result of the collapse of the USSR. Most countries responded by increasing the tax burden, fighting offshore centers, increasing regulatory pressure (especially in countries with developed banking systems). The large number and depth of financial crises (especially debt) have created favorable conditions for entry into the banking markets of many countries. All this in the complex stimulated large banks to find opportunities to expand their business. As a result, a new vector of strategic development was created - the development of transnational banks and the expansion of banks to financial 
markets in other countries. The beginning of the 2000s was marked by the collapse of Internet companies, which became analogous to the railway companies during the crisis of 1847 in Europe and the United States. This crisis is called the "dotcom crisis". First we suffered small companies, and later big, even those who worked in the field of Business-to-Business. In 2000-2001, the Nasdaq-Composite index, which reflects the value of the most capitalized high-tech companies, has fallen more than 3 times (from 4700 to 1400). The main cause of this crisis, researchers say excessive investment in the inter-n-company at low financial performance of their activities. At that time, the US dollar for the first time equaled the cost of the Euro and even became cheaper. In the complex, this resulted in the outflow of small private investors from the stock market, and subsequently a recession.

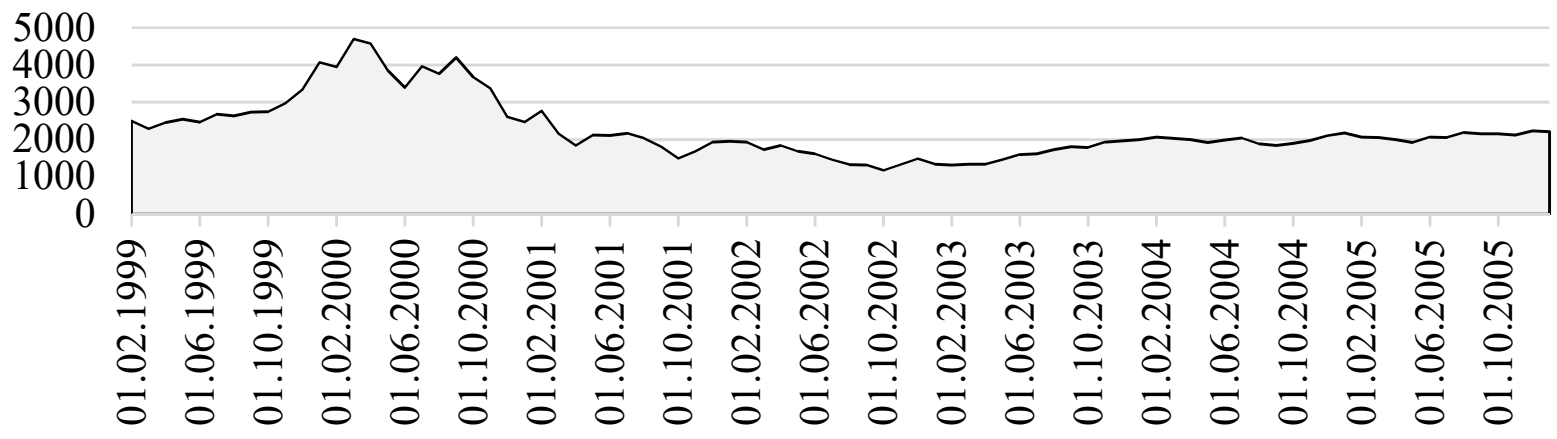

Figure 5. Dynamics of the Nasdaq-Composite index

The last world financial crisis that took place in 2007-2008 has hit most countries of the world, because in many cases it has a complex nature and has hit the developed countries more than any other. And since they often acted as financial donors of less developed countries, then they began to feel the consequences of the crisis. The beginning of this crisis is purely banking and is associated with a massive default on mortgage loans in the United States. The reasons for non-reclamation are also the stagnation in the labor market, and unreasonably high prices for housing, and the extremely high rates of construction of housing with violations of construction norms, resulting in new owners began to abandon him, which caused a chain reaction. In any case, this led to the fact that banks began to put up mortgaged property for sale on a mass scale, which caused a collapse in prices on the real estate market. The first and loudest victim of this crisis was in September 2008 one of the largest US banks - "LEHMAN BROTHERS", the news of which all US stock exchanges collapsed. In parallel, the mortgage crisis has led to a general decline in lending, which led to lower sales in other traditional markets. The spread of this crisis took place in three stages. The first stage started in 2007 and its stimulus was the fall of the indexes of leading exchanges in the USA and the world (Figure 5). As a rule, in such a situation, capital owners are beginning to look for stable markets where the highest profitability can be ensured, which is why they initiated the flow of speculative capital from developed country markets to emerging market countries. By that time (2007), they maintained a high level of growth and profitability. 150

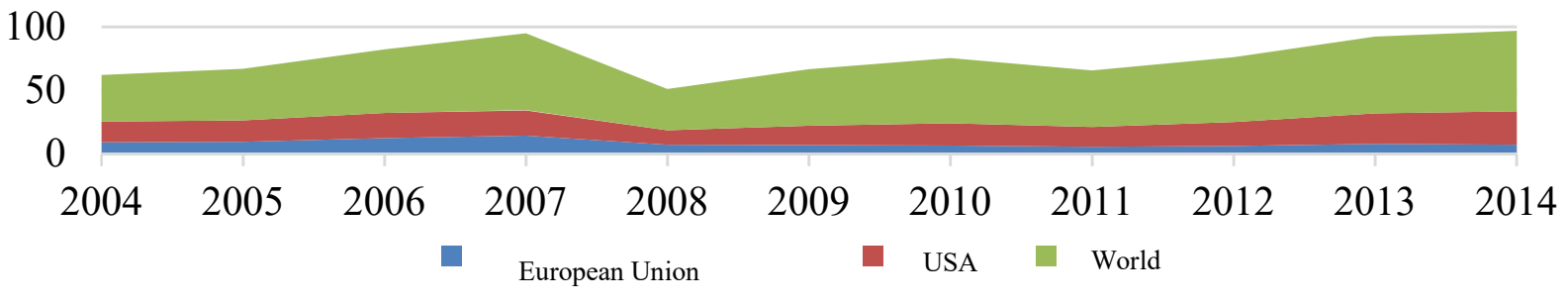

Figure 6. Market capitalization of listed companies during the financial crisis of 2007-2008

The second stage began in January 2008, when, as a result of the collapse of stock markets, financial capital was reoriented from financial assets (in particular, stocks and bonds) in raw materials and energy assets (mainly futures and options). The third stage in the spread of the global financial crisis was caused by a number of bankruptcies of the largest international financial companies and the transfer to the real sector of the financial crisis. This led to a decrease in aggregate demand in world commodity markets and, consequently, a fall in prices in the resource markets (Figure 7), which led to the stagnation of the world's largest economies. 


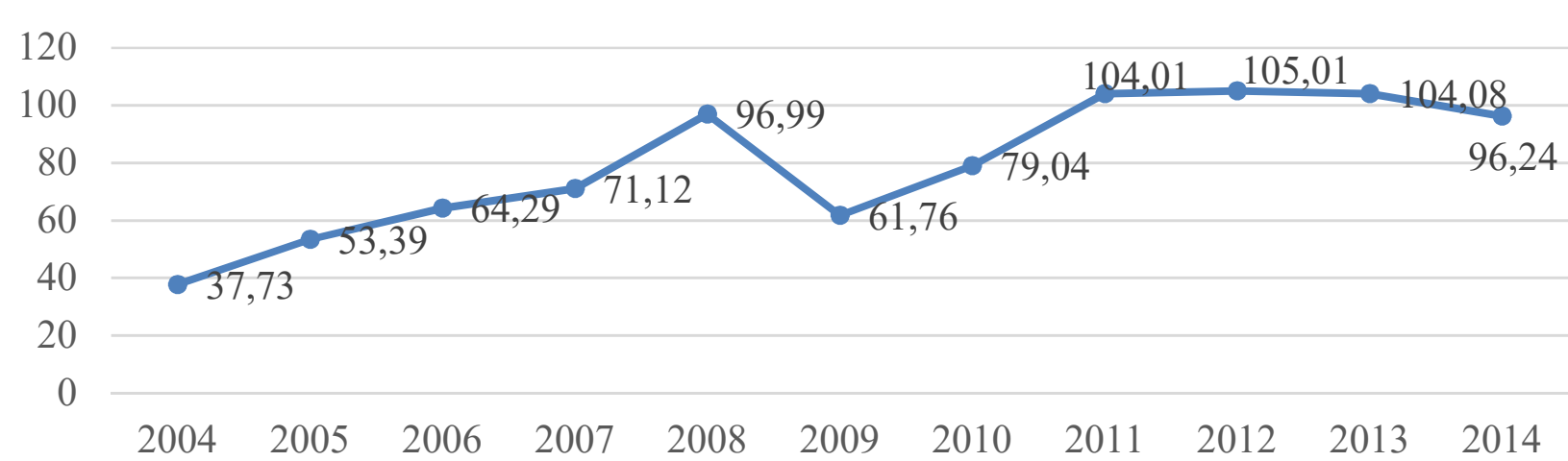

Figure 7. Dynamics of prices for crude oil, USD US \$ per barrel

Summing up the causes and consequences of the financial crises of the XXI century. we can state that the main reasons were the excessive sector concentration of banks and stock market participants: in 2001 (the crisis of dotcoms) they were companies of the IT sector; In 2007-2009 (World FC) these were mortgage loans and construction companies in the US and Western Europe, the rapid development of the market for derivative stock instruments (in the sale of mortgages and oil) and its imperfect regulation. The main measures to combat the causes and consequences of crises in this period were: a change in the regulatory framework for banking regulation (Greem-Licha-Blailey's 1999 law, Basel II in 2004); strengthening of requirements to banks regarding financial stability, volume of bank capital and transparency; risk-oriented approach to banking supervision. In the complex, this led to the formation of a new vector for the development of banks after the completion of the analyzed crises - the restoration of the distinction between traditional banking and investment activities and the development of financial innovations.

\section{Conclusions}

The analysis of the course of the world's largest financial in 1788-2008 allowed us to formulate the following conclusions:

1) During the 19th century, the global financial crises in the overwhelming majority were caused by structural changes in production, sharp changes in labor productivity and protectionist government policies. Typically, after the crises of the 19th century, significant structural changes occurred in the monetary systems of the countries concerned, requiring financial agents to radically rebuild their own strategies;

2) the crisis of the first half of the twentieth century. were characterized more by the collapse of stock markets, this was due to the rapid development of new stock instruments and the sharp flow of capital between different parts of the world (USA, Europe, Latin America). The main problem of the crises of the first half of the twentieth century. was the restoration of public confidence in financial institutions and the struggle with the outflow of bank deposits, it was during this period that the first system of guaranteeing deposits in the US was introduced and the famous Glass-Stigol Act was adopted;

3) the causes of the global financial crises of the second half of the twentieth century. there were price bubbles in the oil market and sharp capital inflows between financial centers. A particular feature of these crises was the entry into the international capital markets of China and the expansion of the geography of the spread of global financial crises - they have become more extensive in the number of countries covered. In addition, the collapse of the USSR at the end of the twentieth century. has caused the high volatility of international flows of investment capital. The main trend of post-crisis development of financial agents in this period was the active development of transnational financial corporations;

4) the crisis of the XXI century. (there were only 2 of them, the crisis of dotcoms in 2001 and the crisis of 2007-2009) was characterized by excessive concentration of both banks and stock market players in one sector - in 2001 they were IT companies, in 2007 it was a real estate sector. The main trend of postcrisis development of financial institutions during this period was diversification of the portfolio of assets and the delineation of investment and traditional financial activities.

As a result, we note that scientific literature distinguishes 8 world economic crises $-1857,1907,1920$, 1929-1933, 1937, 1957, $1974-1975$ years, 2007-2008. The most crisis year in the world for the period of 1970-2007 was 1994, during which there were 25 banking, 11 currency crises and 2 double crises, 
separately should also be allocated in 1998 with 7 currency, 10 bank, 2 debt, 3 double and 3 triple crises. All of the above-mentioned financial crises, in combination with mono-regional and regional crises, have formed the four main global vectors of strategies for the operation of financial agents in the markets (Table 1).

Table 1. Results of the study of transformations in the chain "financial crisis - anti-crisis policy of regulators - change in the vector of strategies of financial agents in the financial markets" (1788-2008)

\begin{tabular}{|c|c|c|c|c|}
\hline $\begin{array}{l}\text { Global vector of strategies of fi- } \\
\text { nancial agents in the financial } \\
\text { markets }\end{array}$ & Period & $\begin{array}{l}\text { Regions of } \\
\text { spread of finan- } \\
\text { cial crises }\end{array}$ & $\begin{array}{l}\text { Causes of financial crises, which became a } \\
\text { catalyst for changing the vector of strategies } \\
\text { of financial agents in financial markets }\end{array}$ & $\begin{array}{l}\text { Regulatory actions that have led to } \\
\text { a change in the venture strategy of } \\
\text { financial agents in financial mar- } \\
\text { kets }\end{array}$ \\
\hline $\begin{array}{l}\text { Specialization of activities of fi- } \\
\text { nancial agents in financial mar- } \\
\text { kets }\end{array}$ & XIX & $\begin{array}{l}\text { Several world } \\
\text { financial crises }\end{array}$ & $\begin{array}{l}\text { Structural changes in production and in the } \\
\text { monetary systems of countries, sharp } \\
\text { changes in labor productivity, the difference } \\
\text { in profitability and the riskiness of certain } \\
\text { types of economic activity }\end{array}$ & \\
\hline $\begin{array}{l}\text { Retail financial services } \\
\text { development }\end{array}$ & $\begin{array}{l}\text { I half of the twen- } \\
\text { tieth century. }\end{array}$ & $\begin{array}{l}\text { USA, Europe, } \\
\text { Latin America }\end{array}$ & $\begin{array}{l}\text { The collapse of stock markets, the burgeon- } \\
\text { ing development of new stock instruments, } \\
\text { the sharp flow of capital between different } \\
\text { parts of the world, large volumes of specu- } \\
\text { lation, weak regulation of the stock market }\end{array}$ & $\begin{array}{l}\text { The policy of restoring public con- } \\
\text { fidence in financial institutions, } \\
\text { fighting the outflow of bank de- } \\
\text { positories, introducing the first de- } \\
\text { posit guarantee system in the US, } \\
\text { adopting the Glass-Stigol Act }\end{array}$ \\
\hline $\begin{array}{l}\text { Development of transnational } \\
\text { financial companies, expansion } \\
\text { of financial agents to financial } \\
\text { markets of other countries }\end{array}$ & $\begin{array}{l}\text { Second half of the } \\
\text { twentieth cen- } \\
\text { tury.. }\end{array}$ & $\begin{array}{l}\text { Several global } \\
\text { financial crises } \\
\text { (expanded geog- } \\
\text { raphy of coun- } \\
\text { tries) }\end{array}$ & $\begin{array}{l}\text { Price booms in the oil market, sharp capital } \\
\text { flows between financial centers, China's } \\
\text { exit into international capital markets, high } \\
\text { volatility of international flows of invest- } \\
\text { ment capital as a result of the collapse of the } \\
\text { USSR }\end{array}$ & $\begin{array}{l}\text { Increasing tax burden, fighting } \\
\text { offshore centers, increasing regu- } \\
\text { latory pressure in developed fi- } \\
\text { nancial systems }\end{array}$ \\
\hline $\begin{array}{l}\text { Separation of investment and } \\
\text { traditional financial and bank- } \\
\text { ing activities }\end{array}$ & XXI & $\begin{array}{l}\text { USA, global } \\
\text { financial crisis }\end{array}$ & $\begin{array}{l}\text { Excessive industry concentration of banks } \\
\text { and stock market participants: in } 2001 \text { (cri- } \\
\text { sis of dotcoms) - companies of the IT sector; } \\
\text { in } 2007-2009 \text { (global financial crisis) - the } \\
\text { real estate sector in the US and Western Eu- } \\
\text { rope, the rapid development of the market } \\
\text { for derivative stock instruments, its imper- } \\
\text { fect regulation }\end{array}$ & $\begin{array}{l}\text { Changing the regulatory frame- } \\
\text { work for banking regulation } \\
\text { (Greem-Licha-Blailey's } 1999 \text { law, } \\
\text { Basel II in 2004), the strengthen- } \\
\text { ing of the requirements for finan- } \\
\text { cial autonomy, financial sustaina- } \\
\text { bility, capital, transparency, risk- } \\
\text { oriented approach to supervising } \\
\text { activities of financial institutions }\end{array}$ \\
\hline
\end{tabular}

Thus, for the formation of effective strategies for the activities of financial agents in the post-recurrence period, the probability of appearance and depth of derivative financial crises that arise during or after the completion of the underlying crisis should also be taken into account.

\section{References}

1. Ahmed, S., C. Takeda and S. Thomas. (1999). Bank Loan Loss Provisions: A Reexamination of Capital Management, Earnings Management and Signaling Effects. Journal of Accounting and Economics, 28, 1-25.

2. Aizenman, Joshua and Y. Jinjarak. (2009). Current Account Patterns and National Real Estate Markets. Journal of Urban Economics, 66(2), 75-89.

3. Alessi, L. and Detken, C. (2011). Quasi Real Time Early Warning Indicators for Costly Asset Price Boom/bust Cycles: A Role for Global Liquidity. European Journal of Political Economy, 27(3), 520-533.

4. Allen N. Berger, Robert DeYoung, Hesna Genay and Gregory F. Udell. (2000). Globalization of Financial Institutions: Evidence from Cross-Border Banking Performance. RB Chicago Working Paper No. 1999-25.

5. Allen, F., A. Babus, and E. Carletti. (2009). Financial Crises: Theory and Evidence, Annual Review of Financial Economics, 1, 97-116.

6. Allen, R. E. (2010) Financial Crises and Recession in the Global Economy, Edward Elgar Publishing, 3rd Edition.

7. Arthur E. Wilmarth Jr. Does Financial Liberalization Increase the Likelihood of a Systemic Banking Crisis? Evidence from the Past Three Decades and the Great Depression. (2003) - Benton E. Gup, ED., Too-Big-To-Fail: Policies and practices in government bailouts

8. Awrey, D. (2012). Complexity, Innovation and the Regulation of Modern Financial Markets. - Harvard Business Law Review 235-294, Oxford Legal Studies Research Paper No. 49/2011

9. Babecký, J., Havránek, T., Matějů, J., Rusnák, M., Šmídová, K. and Vašíček, B. (2012). Leading Indicators of Crisis Incidence: Evidence from Developed Countries. Czech National Bank, mimeo

10. Balasubramanyan, Lakshmi, Saeed Zaman, and James B. Thomson. (2014). Are Banks Forward-Looking in Their Loan-Loss Provisioning? Evidence from the Senior Loan Offi cer Opinion Survey (SLOOS) Federal Reserve Bank of Cleveland, working paper no. 13-13R 
11. Banking, debt, and currency crises early warning indicators for developed countries. Jan Babecký, Tomáš Havránek, Jakub Matějů, Marek Rusnák, Kateřina Šmídková and Bořek Vašíček // European central bank Working paper series №1485 / October 2012.

12. Barrell, R., Davis, E. P., Karim, D. and Liadze, I. (2010). Bank Regulation, Property Prices and Early Warning Systems for Banking Crises in OECD Countries. Journal of Banking \& Finance, 34(9), 2255-2264.

13. Beatty, A. and Scott Liao. (2009). Regulatory Capital Ratios, Loan Loss Provisioning and Pro-Cyclicality," Ohio State University Working Paper.

14. Beck, T. (2016). Regulatory Cooperation on Cross-Border Banking - Progress and Challenges After the Crisis. National Institute Economic Review, 235(1).

15. Beck, T. and Brown, M. (2015). Foreign bank ownership and household credit. Journal of Financial Intermediation, 24(4), 466-486.

16. Bussiere, M. and Fratzscher, M. (2006). Towards a New Early Warning System of Financial Crises. Journal of International Money and Finance, 25(6), 953-973

17. Calvo, Guillermo, Leonardo Leiderman, and Carmen Reinhart. (1996). Inflows of Capital to Developing Countries in the 1990s. Journal of Economic Perspectives, 10(2), 123-139

18. Capital Flow Waves: Surges, Stops, Flight, and Retrenchment, Kristin J. Forbes and Francis E. Warnock. NBER Working Paper № 17351 August 2011

19. Cetorelli, N., and Goldberg, L. S. (2010). Global Banks and International Shock Transmission: Evidence from the Crisis. NBER Working Papers 15974, National Bureau of Economic Research, Inc. url: http://ideas.repec.org/p/nbr/nberwo/15974.html

20. Claessens, S., and van Horen, N. (2011). Foreign Banks: Trends, Impact and Financial Stability. DNB Working Papers 330, Netherlands Central Bank, Research Department. url: http://ideas.repec.org/p/dnb/dnbwpp/330.html

21. Claessens, Stijn and Kristin Forbes. (2001). International Financial Contagion: An Overview In Stijn Claessens and Kristin Forbes, eds. International Financial Contagion. Kluwer Academic Publishers, 3-17

22. Claessens, Stijn, Ayhan Kose, M. (2013). Financial Crises: Explanations, Types, and Implications. IMF Working Paper № 13/28

23. Claessens, Stijn, Rudiger Dornbusch, and Yung-Chul Park. (2001). Contagion: Why Crises Spread and How This Can Be Stopped. In Stijn Claessens and Kristin Forbes, eds. International Financial Contagion. Kluwer Academic Publishers, 19-41. 